\title{
Potentialer og problematikker ved livestreaming og fastholdelse af undervisning
}

\section{Sarai Løkkegaard}

PhD studerende

E-learning Lab - Center for User Driven Innovation Learning and Design, Aalborg Universitet

\section{Thomas Ryberg}

Professor mso

E-learning Lab - Center for User Driven Innovation Learning and Design, Aalborg

Universitet

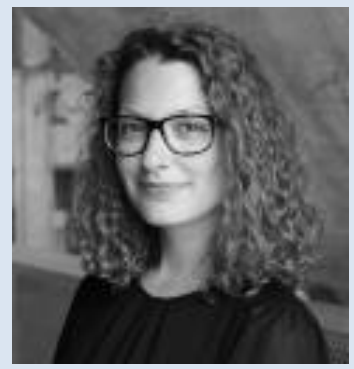




\section{Abstract}

I efteråret 2012 forsøgte vi os med livestreaming af undervisning på 1 . semester af bacheloruddannelsen i Humanistisk Informatik (AAU). Livestreaming var en måde at løse et presserende problem med stort optag af nye studerende og deraf følgende lokalemangel. Samtidig var det en mulighed for at opsamle strukturerede erfaringer med nye undervisningsrum og undervisningsformer. Det er disse erfaringer, vi med udgangspunkt i kvalitative og kvantitative data analyserer og diskuterer i denne artikel. Artiklens formål er at klarlægge, hvilke problematikker og potentialer studerende og undervisere oplever i forbindelse med livestreaming og fastholdelse af undervisning. Rent teknisk oplevede vi store udfordringer, som afstedkom, at vi kort inde i semestret afbrød forsøget med streaming og i stedet dublerede de resterende forelæsninger. Vi nåede dog at få indsamlet data om både studerende og underviseres erfaringer med og holdninger til livestreaming og fastholdelse af undervisning. Disse potentialer og problematikker diskuterer vi med udgangspunkt i vores data og i dialog med eksisterende forskning inden for området.

\section{Introduktion og baggrund}

I efteråret 2012 blev der på 1. semester af bacheloruddannelsen i Humanistisk Informatik (AAU) foretaget en række forsøg med livestreaming af undervisningen. Ved livestreaming skal i denne sammenhæng forstås, at et hold studerende (227) deles op i to grupper og placeres i to forskellige lokaler. Undervisningen foregår i lokale A og livestreames samtidig til lokale B. Der var to primære grunde til forsøgene med livestreaming af undervisningen. For det første gjorde et stort optag samt en begrænset lokalekapacitet, at vi ret akut var nødt til at tænke i nye måder, hvorpå de studerende kunne få samme undervisning og stadig opleve et vist socialt tilhørsforhold til hinanden og studiet. Dette var vigtigt for at opretholde ideen om hele semestret som fællesskab, og derfor var det også vigtigt, at de studerende fik mulighed for at være i bygningerne samtidig. For det andet har det gennem længere tid været studiets ønske at eksperimentere med alternative og medierede undervisningsformer. Livestreaming var derfor en måde at adressere et akut og meget presserende problem, men samtidig en mulighed for begyndende udforskning af nye undervisningsrum. Livestreamingen af undervisning skulle fungere som supplement til dublering af undervisningen. Dublering var ligeledes problematisk på grund af mangel på ledige auditorier og vores ønske om, at de studerende skulle være i bygningerne på samme tid.

Umiddelbart efter forelæsningerne med livestreaming brugte vi tid på at indsamle de studerendes erfaringer, hvilket skete i form af spørgeskemaer. Løbende i semestret afholdt vi desuden kvalitative interviews med både studerende og undervisere. Det indledende mål med særligt 
spørgeskemaerne var at undersøge, hvorvidt de studerende ville opleve en signifikant forskel mellem forelæsningslokalet og streaminglokalet, $\mathrm{fx}$ om der ville være forskel i deres oplevelse af kontakt til hinanden og forelæseren, eller om deres koncentrationsniveau ville variere. På grund af de tekniske problemer blev dette imidlertid svært at sammenligne på meningsfuld vis, da det var åbenlyst, at der var store forskelle i betingelserne i de to lokaler. Selvom der er nogle indikationer i spørgeskemaerne omkring kontakt, opmærksomhed og koncentration (som vi kort vender i analysen), er vores primære mål i artiklen derfor at analysere de impliceredes forventninger, oplevelser og holdninger til livestreaming, snarere end at gennemføre en komparativ analyse af de to undervisningssituationer. I denne artikel fokuserer vi derfor primært på at klarlægge, hvilke potentialer og problematikker studerende og undervisere oplever omkring livestreaming og fastholdelse af undervisning, og som derfor kan være relevante at forstå og forholde sig til i en bredere universitetspædagogisk kontekst. Underviserperspektivet er særlig interessant, idet der lader til at være få internationale studier, hvor undervisernes perspektiv og holdninger indgår, som det fremgår af et større review omkring brug af podcasting i undervisning (Kay, 2012).

\section{Forelæsningernes set-up}

I forsøget med livestreaming af undervisning havde vi tre typer lokaler til rådighed:

\begin{tabular}{|l|l|l|}
\hline $\begin{array}{l}\text { Lokale A: } \\
\text { Det store auditorium (1.45) }\end{array}$ & Plads til 200 studerende & $\begin{array}{l}\text { Her blev undervisningen } \\
\text { transmitteret/streamet fra }\end{array}$ \\
\hline $\begin{array}{l}\text { Lokale B: } \\
\text { Det lille auditorium (1.03) }\end{array}$ & Plads til 90 studerende & $\begin{array}{l}\text { Her blev undervisningen } \\
\text { transmitteret/streamet til }\end{array}$ \\
\hline $\begin{array}{l}\text { Lokale C: } \\
\begin{array}{l}\text { To mindre "klasseværelser" } \\
(1.09 \text { og } 1.40)\end{array}\end{array}$ & Plads til 40 studerende & $\begin{array}{l}\text { Her blev undervisningen } \\
\text { transmitteret/streamet til }\end{array}$ \\
\hline
\end{tabular}

Figur 1. Typer af lokaler til rådighed

I alt begyndte 227 studerende på 1 . semester Humanistisk Informatik i Aalborg i efteråret 2012. Af hensyn til planlægning og gennemførelse af undervisningen blev disse inddelt i tre storgrupper. I Lokale A var der således plads til to af de tre storgrupper. Setuppet blev derfor, at der ved hver forelæsning - hvad end den skulle streames eller dubleres - var to hold: ét hvor to storgrupper sad sammen i Lokale A, og ét hvor én storgruppe (eller en halv) sad alene i Lokale B eller C. For at sørge for at alle studerende prøvede samtlige undervisningskombinationer, udviklede vi et rotationsskema, så storgrupperne skiftedes fra gang til gang. 


\section{Indsamling og bearbejdning af data}

Efter flere af forelæsningerne med livestreaming indsamlede vi de studerendes erfaringer vha. et spørgeskema. Som supplement dertil foretog vi fire enkeltmandsinterview og ét to-personers interview med studerende, samt seks enkeltmandsinterview med undervisere.

Kombinationen af interviews og spørgeskema er bredt anvendt inden for en række forskellige studier, der undersøger brug af streaming og podcasting (Heilesen, 2010; Kay, 2012). Mens spørgeskemaerne kan give et bredere, kvantitativt overblik over respondenternes oplevelse, giver interviewene mulighed for at gå mere i dybden med holdninger og oplevelser. Sammenlagt var målet med dataindsamlingen at fastholde de impliceredes erfaringer med forsøgene og læringsudbyttet, både før, under og efter de stod på. Desuden fungerede den ene af artiklens forfattere som observatør/hjælper under hver af de streamede forelæsninger og nedskrev noter med observationer fra de enkelte gange.

\section{Spørgeskemaundersøgelsen}

Spørgeskemaundersøgelse blev udført efter fire af de forelæsninger, hvor vi forsøgte os med livestreaming. I alt har vi godt 400 besvarelser af spørgeskemaet. Antallet af besvarelser varierer fra gang til gang og fordeler sig som følger:

\section{Antal besvarelser fordelt på de forskellige kursusgange}

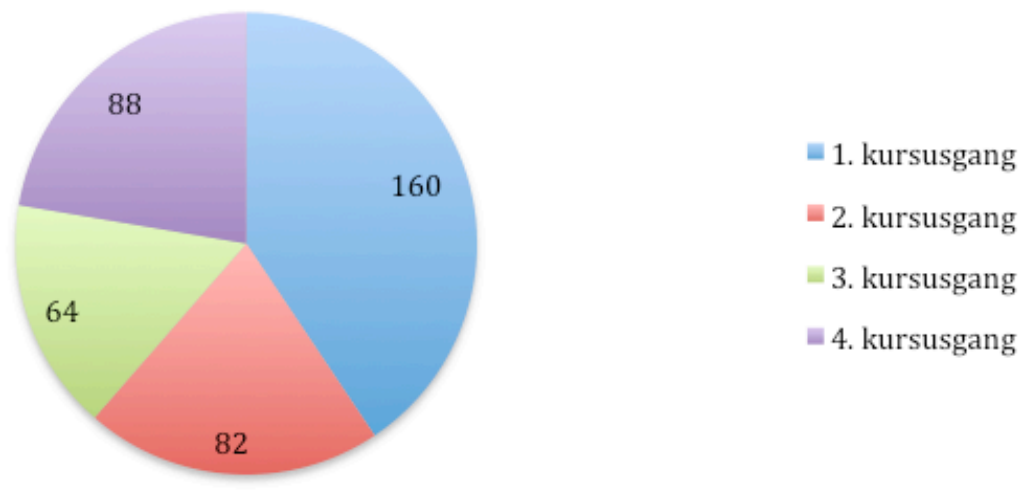

Figur 2. Antal spørgeskemabesvarelser fordelt på de forskellige kursusgange

Målet med spørgeskemaerne var at få adgang til en stor del af de studerendes umiddelbare oplevelser med denne form for undervisning. I spørgeskemaet spurgte vi ind til (1) baggrundsvariabler, hvoraf den væsentligste var, hvilket lokale den enkelte studerende sad i, og (2) den studerendes oplevelse med undervisningsformen (fx de fysiske rammer, 
hvor engagerede de følte sig, og hvordan samspillet var imellem de studerende i situationen). Måden, hvorpå vi derefter primært har bearbejdet dataene, er ved at krydstabulere alle svar ang. oplevelsen af undervisningen med, hvilket lokale den studerende sad i til forelæsningen. På den måde har vi fået en indikation af, hvordan forholdene og oplevelsen varierede i de forskellige rum. Som sagt var betingelserne, grundet de tekniske problemer, dog så forskellige, at en reel og fair sammenligning af forelæsningslokale versus streaminglokale er besværliggjort. Som vi vender tilbage til i analysen, giver materialet dog nogle indikationer, der kan understøtte øvrige analytiske betragtninger.

\section{Interviewene med studerende og forelæsere}

Interviewene med de studerende blev gennemført i slutningen af semestret og altså efter afslutningen af forsøgene med livestreaming. I alt gennemførtes seks interview med studerende. Målet med de kvalitative semi-strukturerede interviews (Kvale, 1997) var at få adgang til uddybende beskrivelser af og refleksioner over de studerendes oplevelser og holdninger i forbindelse med livestreaming af undervisningen. Derudover spurgte vi såvel undervisere som studerende ind til deres tanker om at gøre den optagede undervisning online tilgængelig til senere brug. Empirien relaterer sig således til to forskellige fænomener: 1) livestreaming og 2) fastholdelse til efterfølgende brug.

Halvdelen af interviewene med undervisere gennemførtes, inden den pågældende forelæser havde prøvet livestreaming, mens den anden halvdel gennemførtes efter. Formålet med denne blanding var at få adgang til både forventningerne og oplevelserne med livestreaming. I alt gennemførtes seks semi-strukturerede interview med undervisere. Idéen var, at de undervisere, der blev interviewet inden deres oplevelser med livestreaming, også skulle interviewes efterfølgende. Dette blev dog aldrig aktuelt, da disse undervisere aldrig kom til at afholde deres forelæsning med livestreaming. Interviewene med disse undervisere har dog stadig en værdi i forhold til artiklens sigte, idet der her samtales om nogle af de umiddelbare forventninger og holdninger til det nye undervisningsrum.

Respondenterne blandt underviserne fordeler sig som følger:

I alt gennemførtes seks interview med studerende - alle efter forelæsningernes afslutning. Der blev holdt fire enkeltpersonsinterview (studerende 1-4) og ét to-personers interview (studerende 5-6). 


\begin{tabular}{|l|l|}
\hline Respondent & Pre/post \\
\hline Forelæser 1 & Pre \\
\hline Forelæser 2 & Pre \\
\hline Forelæser 3 & Pre \\
\hline Forelæser 4 & Post \\
\hline Forelæser 5 & Post \\
\hline Forelæser 6 & Post \\
\hline
\end{tabular}

Figur 3. Oversigt over respondenterne

Analysen af interviewene er baseret på en kvalitativ, fortolkende tilgang, hvor vi gennem arbejdet med at foretage, transskribere, behandle og gennemlæse interviewene har forsøgt at fremanalysere en række temaer, som træder frem i materialet i relation til vores ønske om at udforske studerendes og underviseres oplevelser med og holdninger til livestreaming. Indledende er materialet blevet læst igennem flere gange, og en række temaer og undertemaer er blevet udkrystalliseret baseret på de forskellige interviews. Dette er, hvad Kvale (1997) karakteriserer som meningskategorisering, uden at vi dog har kvantificeret forekomsten af kategorierne eller temaerne, som man kan gøre. Disse temaer og undertemaer ( $\mathrm{fx}$ blufærdighed, kontakt, ansigtstab, brug af rum, forberedelse og kontrol) har vi løbende arbejdet med at raffinere og reducere til et mindre antal af mere overordnede temaer, som vi diskuterer nærmere i analysen, hvor vi også behandler nogle undertemaer.

\section{Analyse}

I vores gennemlæsning af særligt de kvalitative interviews er der flere sammenhængende og overlappende temaer, der træder frem, og nogle af dem deles af både studerende og undervisere. Vi har struktureret analysen ud fra to overordnede temaer, der træder tydeligst frem i gennemgangen af det empiriske materiale:

- Kontrol og tab af kontrol - spændfeltet mellem fastholdelse og flygtighed

- Kontakt mellem undervisere og studerende - det sociale og det pædagogiske

Det første tema berøres kun af underviserne, mens det andet nævnes af både studerende og undervisere. Hvert af de overordnede temaer indeholder forskellige undertemaer (fx blufærdighed, kontakt, ansigtstab, brug af rum, forberedelse), som vi berører, men som vi omfangsmæssigt ikke kan behandle særskilt i denne artikel. 


\title{
Kontrol og tab af kontrol - spændfeltet mellem fastholdelse og flygtighed
}

Det første tema, som går på kontrol og tab af samme, er udelukkende identificeret ud fra undervisernes synspunkter. Igennem interviewene med underviserne er det særligt en oplevelse af eller bekymring for 'at tabe kontrollen', som manifesterer sig på forskellig vis. En meget konkret manifestation af dette er den fysiske fastnagling af underviseren på et vist antal kvadratmeter foran tavlen, så vedkommende ikke bevæger sig ud af billedet.

\begin{abstract}
“Det, at der er et kamera, gør også, at jeg bliver begrænset i min måde at bruge rummet på [...] Det er svært bare at stå stille. Og med kamera nytter det jo ikke noget, at jeg render ud af billedet hele tiden. Så jeg tænker, at mit råderum bliver mindre."
\end{abstract}

(forelæser 3, pre)

"Jeg tænker, at noget af det spontane ved undervisningen forsvinder. Jeg er også sådan en person, som bevæger mig meget [...] Og det, synes jeg, var ubehageligt, at jeg skulle holde mig et bestemt sted. Så bliver det meget sådan nærmest dyr i bur sådan stå og hoppe på et sted, og så bliver det halvpinligt."

(forelæser 5, post)

Her kan kameraets fiksering af underviseren læses som en fysisk spændetrøje, der begrænser det kropslige rum, men som ligeledes betyder noget for den "psykiske energi" og oplevelsen af spontanitet og frihed. Fikseringen påvirker således situationen meget direkte, men muligheden for digital fastholdelse af forelæsningen har også en betydning, der tidsmæssigt udstrækker sig til både før og efter. Selve dét, at forelæsningen optages og evt. efterfølgende gøres tilgængelig, indvirker på forskellig vis på underviserne og deres forberedelse til forelæsningen. På den ene side i forhold til personlig og faglig fremtræden:

"[...] og så bliver man lige pludselig meget mere bevidst om tøj og hår, fordi det nu skal filmes."

(forelæser 4, post)

“[...] der er en større grad af blufærdighed i det, fordi det er ens hele person, der er på, men det er jo strengt taget ikke så anderledes, end når ens skrevne tekst bliver offentliggjort. Det er jo også et fagligt produkt, man leverer. Men selvfølgelig vil jeg da tage pænt tøj på og prøve at fremstå sådan rimeligt vederhæftig. 
Skulle nogen nu komme til at se det. Men jeg ser ikke noget større problem i det."

(forelæser 2, pre)

På den anden side handler det også om selve indholdet af forelæsningen, når nu dette bliver fastholdt digitalt. Her nævner en af underviserne fx:

"Jeg har nogle eksempler i min undervisning, som jeg overvejede kraftigt, om jeg skulle bruge i den her situation, fordi de er sådan lidt provokerende [...] Hvis jeg fx fortæller frække vittigheder, så vil jeg helst, at det var lukket, og så kunne man genfortælle det, men ikke nødvendigvis genafspille det. Og det brugte jeg faktisk en del energi på at overveje, om jeg skulle bruge det eksempel. Jeg tænker, at hvis det er en form, som bliver gængs, så tror jeg, at jeg vil disciplinere mig selv lidt mere som underviser."

(forelæser 5, post)

I dette citat ses det, at bevidstheden, om at forelæsningen efterfølgende er tilgængelig, fører til refleksioner over, hvad "man" kan og bør sige, og der kan anes elementer af selvdisciplinering eller selv-censur. Dette hænger tæt sammen med følelsen af tab af kontrol med indholdet. Selvom det streamede materiale i vores tilfælde aldrig blev gjort offentligt tilgængeligt, så er underviserne bevidste om, at digitalt materiale er svært at tæmme og hurtigt kan finde vej ud af lukkede rum.

"For selvom det bliver taget ned igen, så ved vi jo, at der altid vil være nogen, der kan få det kopieret osv. [...] Det er jo ikke fordi, at jeg er bange for, at der ligger noget med mig ude på nettet, for der ligger jo alt muligt. Det har man ikke rigtig kontrol over. Men jeg synes i hvert fald, at det er lidt en sårbar situation, man er i som underviser, altså at blive optaget når man ikke sådan $\mathrm{i}$ forvejen har tilrettelagt det efter, at det skal være en form for foredragsperformance. For der er alligevel en forskel på det og en forelæsning."

(Forelæser 1, pre)

Forelæsningsrummet som et særligt kommunikativt og intimt rum I materialet fremgår det også, at forelæsningen opleves af underviserne som noget kvalitativt andet end et mere planlagt foredrag. Her bruger underviserne ofte begreber som 'flygtig', 'spontan' og 'improviseret' til at karakterisere forelæsningerne. Selvom de i princippet er offentlige og ofte 
holdes for et stort "publikum", så lader det til, at der blandt underviserne er en oplevelse af forelæsningen som et mere "intimt rum":

"[...] forelæsningsrummet og den flygtige interaktion har nogle andre fordele, for du kan arbejde fx med kontroversielle perspektiver, noget som er politisk følsomt, du kan diskutere aspekter, som har en aktualitet, fordi det lige er sket. Og det kan man lægge ind i sammenhængen. Og sådan nogle ting misser man jo også, idet man begynder at lave de optagelsesformer. Og det, synes jeg, ville være rigtig ærgerligt. Fordi mange af de evner til at forklare noget relativ abstrakt og svært teori kommer netop ud af, at man lige kan gribe en situation, fordi det fx var i pressen $i$ morges. Og den improvisationsmulighed er væk."

(forelæser 6, post)

Forelæsningsrummet er noget, der tillader frække vittigheder og mere kontroversielle emner, men det er ligeledes karakteriseret ved en aktualitet og situerethed, som tænkes udfordret af fastholdelsen. Det er tydeligt, at underviserne opfatter forelæsninger som noget, der delvist er improviseret og "efemeralt", dvs. er tids- og stedsligt indkapslet kommunikation. Dels vedrører dette, hvad der kan siges i situationen, men også hvad der faktisk vil give mening efterfølgende ( $f x$ et år senere). Fastholdelsen udfordrer således på flere punkter forelæsningsgenren. Både i relation til forberedelse af forelæsningen, men også som denne udfolder sig konkret i auditoriet. Samtidig er problematikkerne omkring kontrol og fastholdelse også særligt knyttet til, hvad der på længere sigt kan ske med videoerne. I forhold til de studerende er der blandt underviserne dels en bekymring for, hvad fastholdelse kan betyde i relation til at "blive holdt op på udsagn", og dels hvilken vægt studerende tillægger dét, der siges under en forelæsning.

"For de studerende har jeg tit oplevet en tendens til at bruge undervisers slides som kildemateriale på linje med publicerede bøger og artikler og ligesom tage det for gode varer, altså underviserens formidling af de ting, som ikke er ment til det, det har jo ikke været igennem peer review. Det er jo bare sådan noget, man står og siger, når man skal forklare ting. Og det kan være endnu en ting, hvor de kan sige, "jamen du sagde der i minut 12 sådan og sådan", men hvor det måske ikke helt var sådan, man mente det, eller det kan blive taget ud af kontekst."

(forelæser 1, pre) 
Her træder det igen frem, at forelæsningen som genre er en mere "sårbar" størrelse, hvor der måske siges ting, som mere har form af improvisation end som udelukkende velforberedt viderebringelse af eksisterende "videnskabelige fakta".

Forelæesningen forlader det intime rum

Ligesom der er en bekymring for de studerendes autoritetstro til forelæsningen, er der også en vis bekymring for det modsatte, nemlig at forelæsningen kan re-mixes og udsættes for, hvad man kan kalde en kreativ re-appropriering:

"Men sådan noget med, at det lige kunne være sjovt at klippe mig ind i en eller anden sammenhæng, det ville jeg være så træt af. Vi lever jo også i en verden, hvor alting kan deles på alle måder."

(forelæser 4, post)

Den digitale fastholdelse og de øgede muligheder for hurtig distribution gennem sociale medier gør, at sådant materiale er, hvad boyd (2010) betegner som persistent, replicerbart, skalerbart og søgbart. Selvom sådan persistens og adapterbarhed nævnes i forbindelse med de studerende, er det dog ikke dem, der er hovedbekymringen. Tabet af kontrol med det fastholdte materiale er nærmere genstand for bekymring i relation til job og ledelse, og indeholder en bekymring for at blive inspiceret, men også overflødiggjort.

"Men når man bliver foreviget, om det så kommer til at ligge et andet sted. Så hvor er det lige, det ligger henne? Hvad nu hvis jeg en dag skal finde et andet job, og min potentielle arbejdsgiver googler mig og finder nogle gamle forelæsninger? Det kan både være uhensigtsmæssigt eller en fordel, pointen er bare, at jeg ikke selv har kontrollen over det. Men det er nu ikke noget, jeg ligger søvnløs over. Men jeg tænker, at det er vigtigt, at det er noget, man udvikler retningslinjer for, ligesom man har fx en itpolitik, at der ligger et dokument, der klart siger, hvor det her ryger hen."

(forelæser 3, pre)

"Jeg vil ikke have, at undervisningen blot blev genanvendt, men jeg vil gerne selv anvende båndet i undervisning, hvis jeg selv forestår fx øvelser, spørgsmål eller dialog omkring undervisningen."

(forelæser 5, post) 


\begin{abstract}
"Og det er også meget det, jeg hører fra mine kollegaer. Er det her noget, som vil blive brugt til at erstatte mig, kommer jeg så ikke til undervise igen næste år? Får jeg mine timer næste år, bliver vi ikke bare alle sammen overflødige? Og det er jo gode spørgsmål. Men det er jo så slet ikke det, der er intentionen."
\end{abstract}

(forelæser 3, pre)

Særligt overvejelserne, omkring hvad fastholdelsen kan komme til at betyde i relation til arbejdslivet, giver grund til uklarheder. Vi vil ikke kalde det direkte bekymringer, men mere usikkerheder omkring, hvad der potentielt kan ske. Problematikken omhandler, hvem der egentlig har retten til det fastholdte material. Kan universitetet fx påberåbe sig rettigheden til at "genudsende" samme forelæsninger fra år til år og dermed overflødiggøre nogle undervisningstimer? Må institutionen bruge det i andre (nye) kurser? Dette er spørgsmål og usikkerheder, som også Rattleff og Holm (2009) peger på, og hvor der kun få steder på universiteterne lader til at være egentlige aftaler mellem undervisere og institution (Højsgaard, 2013). Vi ser dog, at usikkerhederne bliver slået lidt hen af underviserne selv, for "det er jo så ikke intentionen", men det er faktisk tydeligt, at der kan ligge nogle organisatoriske og fagpolitiske problemstillinger mellem universiteterne og de ansatte. Spørgsmålet om kontrol bliver således meget direkte et spørgsmål om ejerskab eller ophavsret i forhold til det fastholdte materiale. For som det også kan læses af besvarelserne, kan nogle af underviserne også se en pædagogisk ressource i at kunne genbruge og tilgængeliggøre eget optagede materiale.

\title{
Kontakt mellem undervisere og studerende - det pædagogiske og sociale
}

For såvel undervisernes som de studerendes vedkommende er temaet om kontakt gennemgående, og det er et tema, der kan identificeres i såvel interview som i spørgeskemaundersøgelsen. Det er primært bekymringer og problematikker i forhold til mangel på kontakt, respondenterne bringer op, men som følge af setuppet viser der sig dog også potentialer.

For undervisernes vedkommende er det primært en bekymring om manglende kontakt til de studerende og en deraf følgende manglende fornemmelse for egen præstation, der nævnes. At en del af de studerende rent fysisk sidder i et andet rum, synes at påvirke undervisernes "fornemmelse" for forelæsningens forløb, hvilket kan influere på deres egen faglige præstation:

"Man har ikke de studerende sammen i samme rum, så den der situation, man sidder i, hvor de ser en, og man ser, at de ser en, og 
man kan også fornemme, om de nikker og hører efter, hvad man siger og alle de ting, den har man jo ikke rigtig." (forelæser 1, pre)

"Fra mit perspektiv kommer jeg til at mangle noget tilbagekanalisering fra de studerende. Der er selvfølgelig nogen i lokalet, men jeg får ikke en fornemmelse af, hvor de andre er henne. Og selvom en forelæsning primært er envejskommunikation, så betyder det meget for min præstation som underviser, at jeg har en fornemmelse af, om de studerende er til stede."

(forelæser 3, pre)

Det problematiske er, at det bliver vanskeliggjort både at få den mere direkte verbale interaktion, men også den (ofte) non-verbale tilbagekanalisering, der kan give underviseren en oplevelse af de studerendes opmærksomhed, tilstand og forståelse, og som giver muligheden for løbende at justere på forelæsningen. Her fremhæver en respondent dog også, at dette faktisk ikke var så stort et problem, fordi der stadig er studerende til stede i Lokale A:

"I forhold til selve undervisningssituationen, der synes jeg ikke, at det var særligt anderledes eller særligt intimiderende eller mystisk. Det havde jeg nok egentligt tænkt, at jeg ville synes, at det var. Men jeg oplevede det egentlig naturligt, fordi der sad så mange studerende i lokalet. Så det var stadigvæk dem, jeg talte til. Det var ikke et kamera, jeg talte til."

(forelæser 5, post)

For de studerendes vedkommende er det særligt kontakten - eller manglen på samme - til underviseren, der er problematisk. Det ses tydeligt ud fra spørgeskemabesvarelserne, som her er eksemplificeret ved de to første kursusgange med livestreaming. 
Til denne forelæsning sad jeg i lokale

Krydset med: Hvordan var kontakten mellem de studerende i lokalet og forelæseren undervejs i forelæsningen? (Sæt gerne flere $\mathrm{x})$

Det var nemt at stille spørgsmål

Det var svært at stille spørgsmål

Det var svært at se forelæseren

Det var svært at høre forelæseren

Der var god kontakt

Kontakten var ikke så god

Ved ikke

Andet (hvad?)

I alt

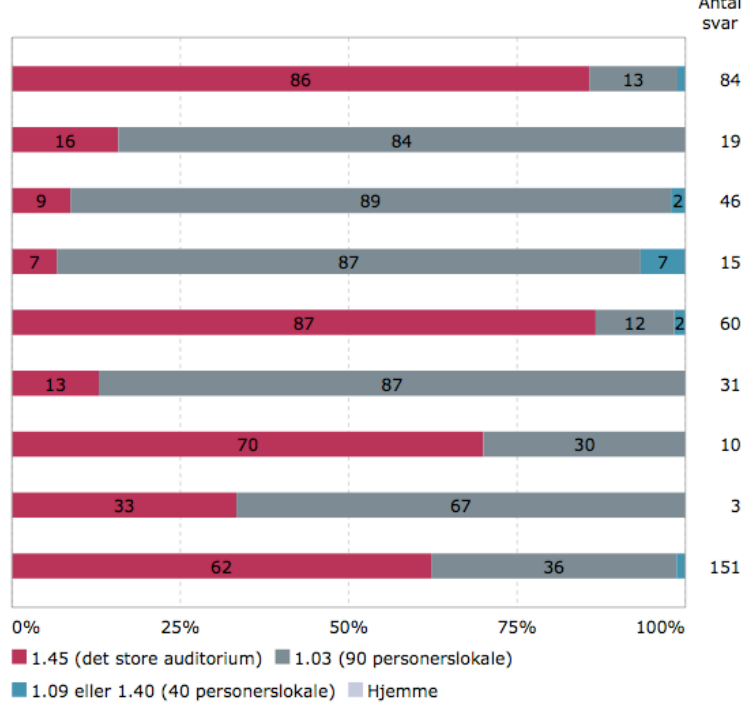

Figur 4. Spørgeskemaresultater: 1. kursusgang med livestreaming. Spørgsmål "hvilket lokale sad du i" krydset med "Hvordan var kontakten mellem de studerende i lokalet og forelæseren undervejs i forelæsningen"

Til denne forelæsning sad jeg i lokale

Krydset med: Hvordan var kontakten mellem de studerende i lokalet og forelæseren undervejs i forelæsningen? (Sæt gerne flere

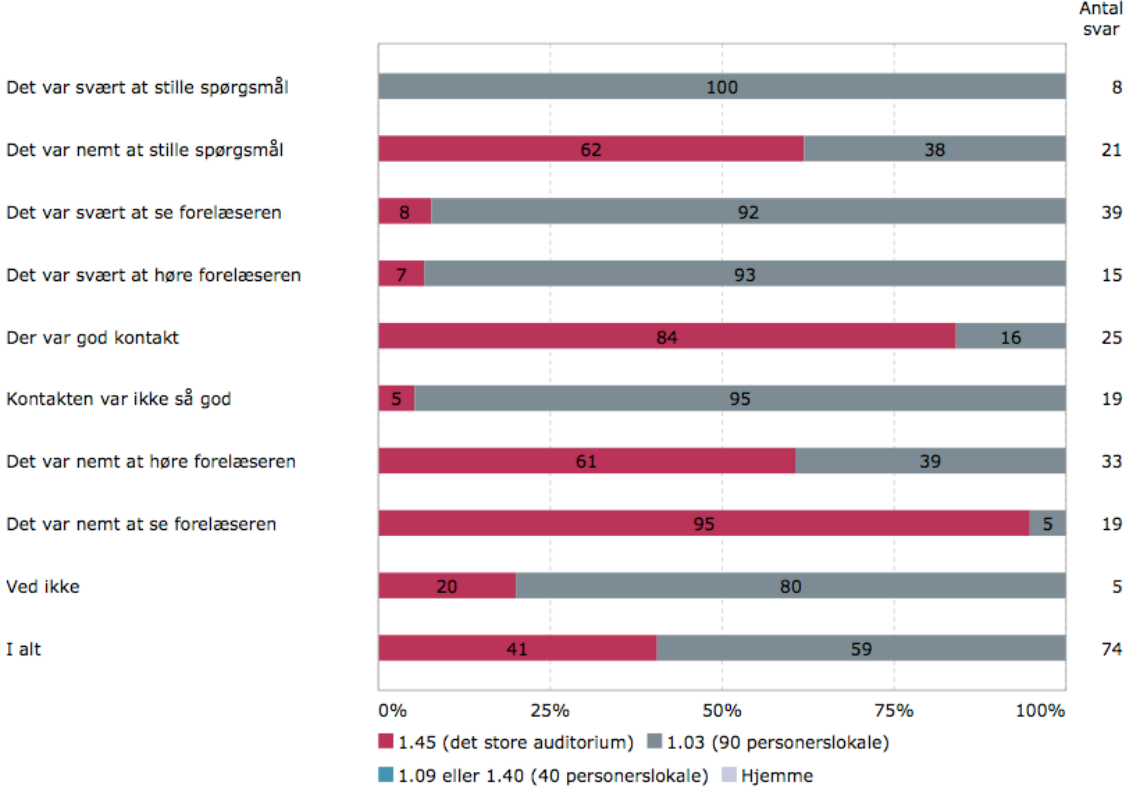

Figur 5. Spørgeskemaresultater: 2. kursusgang med livestreaming. Spørgsmål "hvilket lokale sad du i" krydset med "Hvordan var kontakten mellem de studerende i lokalet og forelæseren undervejs i forelæsningen" 
Besvarelserne i forhold til om det var nemt/svært at se og høre forelæseren og at stille spørgsmål afspejler også vores besvær med at få den tekniske del af løsningen til at fungere optimalt, da det givetvis har influereret kraftigt på de markante inddelinger. I hvert fald ses en tydelig forskel i oplevelsen af kontakt mellem studerende og undervisere i de to lokaler. Kigger vi i de kvalitative besvarelser fra interviewene med studerende, kan vi ydermere identificere nogle af de konsekvenser det har i praksis for de studerende:

\section{"[...] så er det ret svært, når underviseren bare er en skygge på tavlen. Især hvis stoffet er meget svært, så bliver det endnu sværere at holde koncentrationen. Så jo sværere fagligt stof, jo sværere bliver det at sidde i det streamede lokale."}

\section{(studerende 3)}

"Det er simpelthen nemmere at forstå meningen med noget, når man kan se forelæseren. Det ville også være endnu nemmere, hvis man samtidig kan se deres ansigt og deres mimik, og det forsvinder på streamingen."

\section{(studerende 2)}

"[...] hvis personen flakker rundt $\mathrm{i}$ hele lokalet eller ikke rigtig beskæftiger sig med os, der sidder i det andet lokale, så kan man meget hurtigt komme til at føle sig meget fjern fra der, hvor det sker, og så føler man sig ikke specielt velkommen til forelæsningen, så det er relativt vigtigt, at man kan se personen."

\section{(studerende 1)}

Her bliver det at kunne se underviseren fremhævet som et vigtigt aspekt $\mathrm{i}$ forhold til at kunne forstå det faglige stof. Det handler ikke bare om, at det bliver sværere for de studerende at stille eventuelle spørgsmål, men også om at dét fysisk at kunne se underviseren lader til at have en betydning for forståelsen og koncentrationen - et aspekt også fremhævet af andre (McBrien, Cheng, \& Jones, 2009). Ligeledes lader det også til, at der blandt nogle af de studerende er en oplevelse af, at det er vigtigt, at de har en fornemmelse af, at underviseren kan se eller "beskæftiger" sig med de studerende, som sidder i Lokale B/C (en sådan problematik omkring 'blik' (hvem ser på hvem/hvad) er også velkendt inden for telepresence $\mathrm{i}$ relation til oplevelse af samarbejde og kontakt (Cherubini, de Oliveira, Oliver, \& Ferran, 2010)). 
Den medierede versus den ikke-medierede forelæesning

Ovenstående citater kunne dog også læses således, at såfremt det tekniske setup havde fungeret bedre, så ville disse forbehold træde mere i baggrunden. Dette er noget, som flere studerende i interviewene løbende fremhæver: Såfremt det tekniske fungerer, så differentierer livestreaming af undervisning sig ikke stort fra almindelige forelæsninger, da kontakten til underviseren i den oprindelige form alligevel er begrænset:

"Jeg kan på ingen måde se nogen forskel i at sidde i et streaminglokale fremfor at sidde overfor forelæseren. Især også når vi slet ikke interagerer særlig meget. Så har jeg ikke behov for at kunne se ham fysisk, så længe jeg kan høre og forstå, hvad der bliver sagt."

(studerende 4)

"Men selve det der med, at jeg skal sidde i et andet lokale, og jeg kun har forelæseren på en skærm, det gør mig egentligt ikke så meget. Der er jo stadig mulighed for at stille spørgsmål. Men måske er det lidt nemmere at holde koncentrationen, når der er et levende billede at holde øje med [...]"

(studerende 5)

Såfremt det tekniske setup kommer ordentligt i stand, kunne det altså tyde på, at det ikke er urealistisk, at de studerende kan og vil håndtere denne form for undervisning som et udmærket supplement til den klassiske forelæsning. Der synes dog samtidig at være forskellige holdninger til, hvad "kontakt" indebærer i forhold til vigtigheden af, om der fysisk er en underviser i rummet, eller om det er lige meget. Andre steder pointerer studerende fx:

"Det ville gøre det meget sværere at lære noget, for der ville ikke være mulighed for dialog og opklarende spørgsmål, og så kommer man til at mangle den der menneskelige kontakt."

(studerende 3)

"Men selvom jeg ikke er modstander af streaming, så ville jeg ikke kun sidde i de lokaler, vi streamer til, for jeg vil også en gang imellem have lov til at sidde og kigge på et rigtigt menneske. Jeg vil have lidt afveksling i det. Så jeg synes, man skal skiftes lidt til at tage den tørn."

(studerende 5) 
Så selvom man forestillede sig, at det tekniske setup virkede perfekt, kan der være variationer i de studerendes oplevelse af den medierede versus den ikke-medierede forelæsning - også i relation til oplevelsen af at være "inkluderet og velkommen" snarere end "ekskluderet og glemt".

Ovenstående bevidner, som det også ses af andre studier (McBrien et al., 2009; Teng, Chen, Kinshuk, \& Leo, 2012), at selve oplevelsen af "presence" (tilstedeværelse) er kompliceret, og at den varierer blandt studerende. På den ene side bekræfter andre studier, at teknisk dårlig kvalitet kan øge den oplevede distance, men samtidig fremhæver de også, at oplevet tilstedeværelse ikke kun afhænger af teknikken. Også andre faktorer indgår, som det fx fremhæves i Community of Inquiry (CoI) frameworket (Garrison, Anderson, \& Archer, 1999), hvor der skelnes mellem Cognitive, Social \& Teaching presence - eller hos Moore (1993), hvor dialog, struktur og lærendes mulighed for autonomi, som væsentlige aspekter af oplevet distance. Begge disse rammeværk er dog specielt blevet fremhævet i relationer til studier, hvor der er tale om mere dialogiske læringsformer, end stor-forelæsninger typisk er.

\section{Potentialer for øget interaktion under forelæsningerne}

Når det kommer til kontakten og interaktionen de studerende imellem ses dog også nogle interessante indikationer af et potentiale for interaktion og videndeling mellem de studerende i Lokale B/C. Dette ses især tydeligt ved resultaterne fra 1. kursusgang:

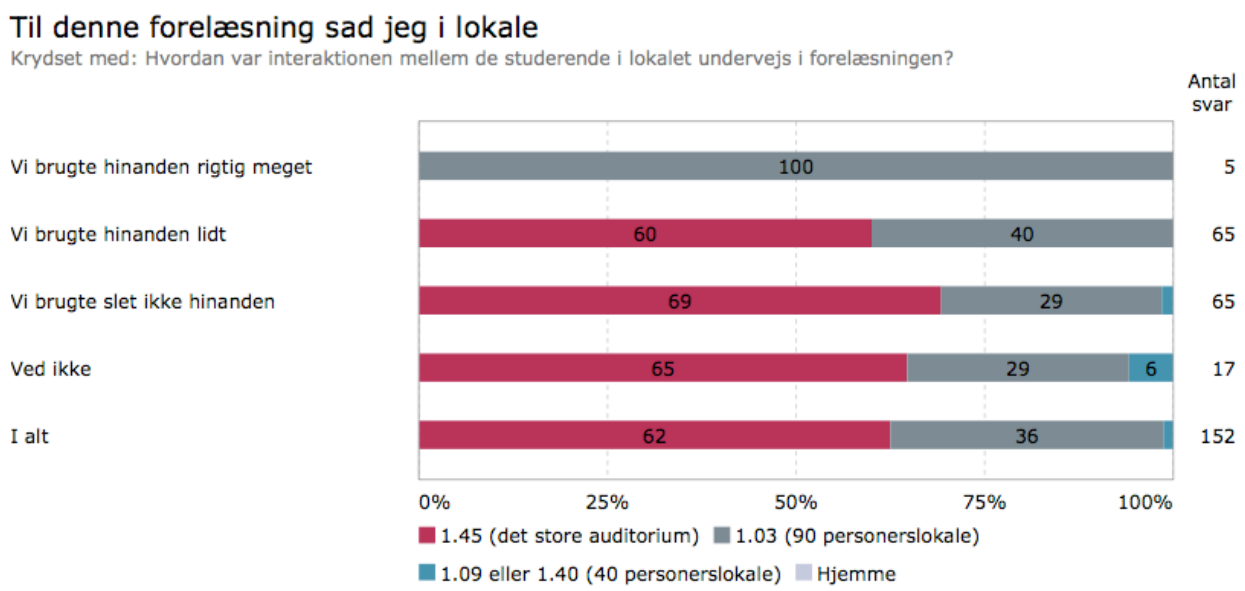

Figur 6. Spørgeskemaresultater: 1. kursusgang med livestreaming. Spørgsmål "hvilket lokale sad du i" krydset med "Hvordan var interaktionen mellem de studerende i lokalet undervejs i forelæsningen" 


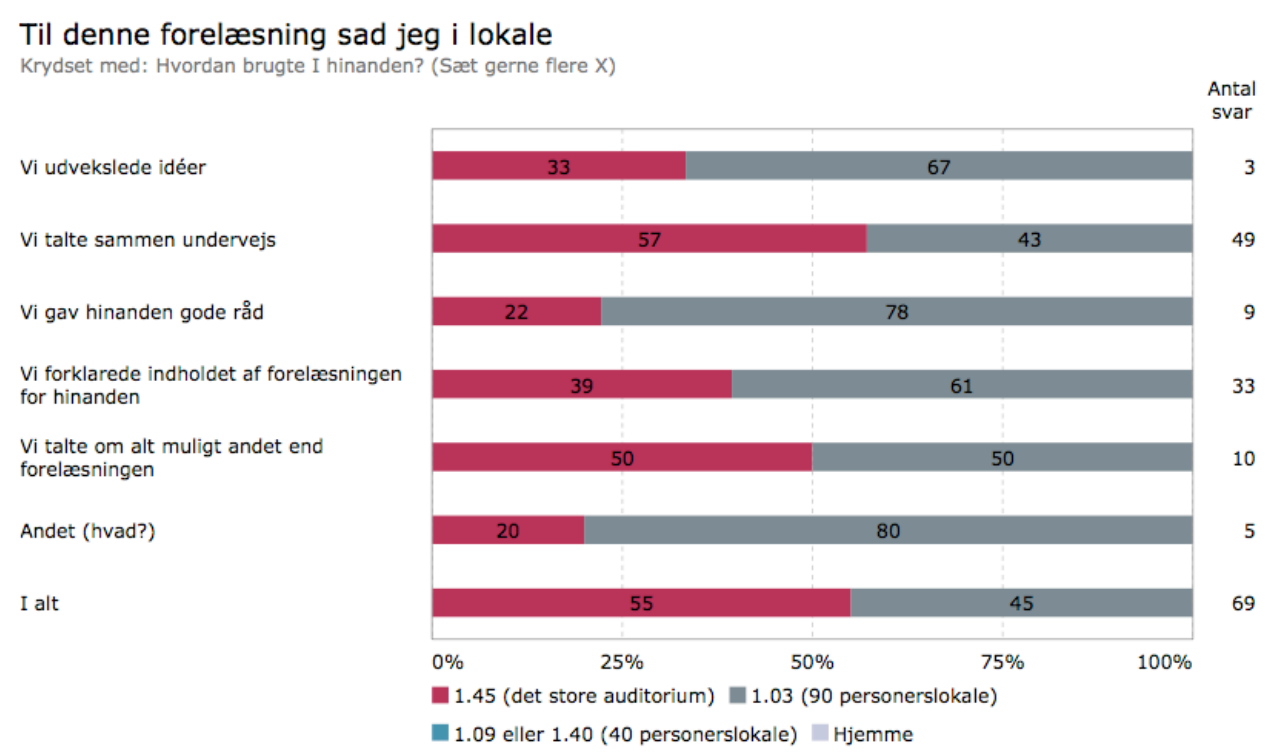

Figur 7. Spørgeskemaresultater: 1. kursusgang med livestreaming. Spørgsmål "hvilket lokale sad du i" krydset med "Hvordan brugte I hinanden (sæt gerne flere X)"

Som spørgeskemaresultaterne indikerer, bruger de studerende i Lokale B/C i højere grad hinanden, end det er tilfældet i Lokale A. En studerende uddyber dette:

"[...] man danner måske et lidt tættere bånd, når man sidder der. Også fordi man her i starten har tænkt, at sidder vi nu her igen, hvor der ikke er noget, der virker. Så vi hjælper hinanden mere i det lokale."

(studerende 1)

Læringsmæssigt må dette betragtes som en potentiel fordel, som i det traditionelle forelæsningsrum ville blive anskuet helt modsat, nemlig som en forstyrrelse: Det er normalt ikke acceptabelt at sidde og snakke med sidemanden, når underviseren taler. Den manglende tilstedeværelse af underviseren i Lokale $\mathrm{B} / \mathrm{C}$ kan altså også medføre den positive konsekvens, at de studerende i højere grad samarbejder om forståelse og meningsforhandling. Og det er ligeledes et potentiale, flere undervisere identificerer:

"Der er stor forskel på, om man sidder i det lille eller store lokale. For jeg vil da håbe, at dem inde i det andet rum, hvis jeg siger et eller andet, så tør sige "hvad sagde hun der, det forstod jeg ikke" osv. Hvis de havde sådan en dialog, det ville jeg synes var rigtig godt. Det kan man jo ikke i det store auditorium." 
(forelæser 4, post)

"Jeg havde engang en oplevelse med, at de studerende faktisk havde en kommunikation indbyrdes på Facebook eller Skype. En skriftlig kommunikation indbyrdes - det, der i gamle dage ville svare til at sende sedler rundt. Og det, synes jeg, er vældig interessant og har nogle muligheder. Det, der så her er interessant, er, at den, der underviser, ikke kan tage hensyn til det, når man ikke ved, det er der. Og det samme vil gælde, hvis de studerende i det lille lokale begynder på en interessant diskussion, som man måske ville vurdere, de skal have plads til. Men eftersom jeg ikke ved det, vil jeg bare køre videre, og så står de måske helt af."

(forelæser 3, pre)

Som begge citater illustrerer, åbnes der også fra undervisernes synspunkt op for nye læringsmuligheder hos de studerende, når undervisningen går fra traditionel forelæsning til såvel livestreaming som adgang til fastholdt materiale. I forhold til livestreaming pointerer forelæser $3 \mathrm{dog}$, at det grundet envejskommunikationen fra Lokale A til Lokale B/C kan være svært som underviser at udnytte dette potentiale for at følge op på sådanne interessante diskussioner, som kan opstå blandt de studerende. En anden underviser pointerer i samme forbindelse, at rummet åbner op for en løsere organisering blandt de studerende, hvilken også kan være fordelagtig for de studerendes måde at lære på:

"Det var interessant, at der var nogle studerende, som egentlig gerne ville sidde inde i det lokale, hvor vi streamede til, og man kunne også se, at de organiserede sig på lidt en anden måde derinde. De sad lidt mere løst og afslappet. Og det er egentlig dybest set den opførsel, man ville have, hvis man bare fik streamet undervisningen fra en server, altså ikke livestream, men i en hvilken som helst anden situation. Altså at man sætter sig derhjemme eller i et grupperum, og så sætter man sig og slapper af med det og fordyber sig i det. Den adfærd, synes jeg egentlig, var ret interessant $[\ldots] "$

(forelæser 5, post)

Dette minder også om den måde, studerende i andre undersøgelser anvender fastholdte forelæsninger (podcast), hvor de positivt fremhæver det at have et privatiseret og afslappet rum omkring sig (Heilesen, 2009; Kay, 2012). 
Potentialer ved repetition og tilgæengelighed

Udover det noget alsidige tema om kontakt til hhv. underviser og andre medstuderende er det fortrinsvis potentialer, de studerende ser ved livestreaming og efterfølgende fastholdelse som undervisningsform. Her er det primære tema "repetition/tilgængelighed". Potentialerne i forhold til at lægge undervisningen online er mangesidede, og det er et tema, der nævnes af samtlige respondenter - både de studerende og undervisere - i de kvalitative interviews.

"Det positive er, at man kan gå ind og gense det."

(studerende 2)

"Og så selvfølgelig også det med, at det bliver lagt ud på nettet, så man kan se det senere, hvis der er noget, man ikke forstod [...]"

(studerende 1)

"Det gode er, at de studerende altid har muligheden for at gå tilbage. Fx den der PBL-del af deres projekt, den kommer de til at skrive i slutningen af deres projekt midt i december, og der kan de måske lige gå tilbage og læse deres papirer, kigge deres slides og måske så også lige høre, hvad det var, forelæser sagde."

(forelæser 4, post)

Det virker måske indlysende, at det attraktive ved denne mulighed er, at undervisningen og læringen bliver fleksibel, idet dens rammer bliver nedbrudt, og det er også aspekter, der går igen i flere andre undersøgelser, som review artiklerne af Heilesen $(2009,2010)$ og Kay (2012) viser. Samtidig viser vores spørgeskemaundersøgelse også, at det er en mulighed, et flertal af studerende ville gøre brug af: 


\section{Hvis denne forelæsning blev optaget og lagt tilgængelig online, ville du så bruge den?}

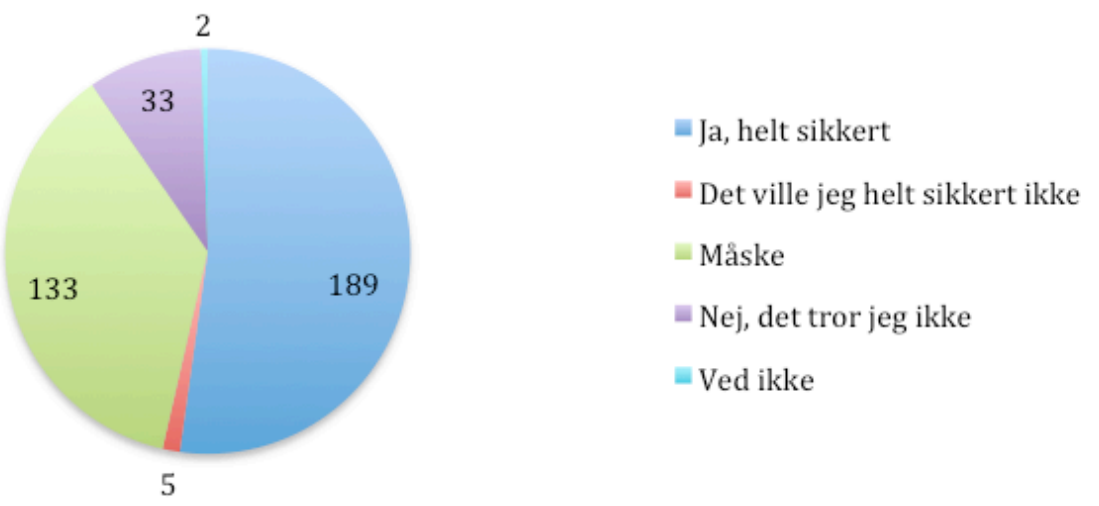

Figur 8. Spørgeskemaresultater: Ville du bruge forelæsningen, hvis den blev lagt online?

I de kvalitative interviews uddyber og fremhæver de studerende nogle af de brugsmuligheder og -situationer, de kan forestille sig:

"Jeg ville bruge det, hvis jeg var i tvivl om noget, eller hvis jeg havde en opgave eller eksamen. Til at få uddybet ting."

(studerende 1)

"Nu er jeg heller ikke vant til at tage noter, og det er faktisk vanskeligt at skulle håndtere det hele, både slides, det sagte og noter. Så det kunne være rart, at man lige kunne zappe ind og høre det igen."

(studerende 2)

"Jeg ville ikke se dem fra en ende af, men hvis jeg lige skulle høre noget bestemt igen. Hvis jeg skulle bruge en teoretiker $\mathrm{fx}$ til en opgave."

(studerende 3)

"Eller hvis man er syg, så kan man finde det, og så behøver man ikke at komme bagud."

(studerende 4)

"Det ville vel også være muligt det med, at man engang imellem kan se det hjemmefra, hvis man fx bor langt væk." 
(studerende 5)

Det er altså både i forhold til de enkelte forelæsningers indhold, noteskrivning, skriftlige opgaver og projekter samt mundtlige eksamener, at potentialet om repetition udspiller sig. Ligeledes er tilgængeligheden en vigtig dimension, dvs. at man kan se det hjemmefra, hvis man er syg, eller hvis man bor langt væk. Denne mulighed for fleksibilitet og for at bearbejde og reflektere over stoffet er også, hvad der oftest fremhæves som potentialer og som øgede læringsmuligheder for de studerende (Heilesen, 2009; Kay, 2012; Rattleff \& Holm, 2009; Rattleff, 2008).

Potentialet i forhold til repetition italesættes faktisk også af underviserne. Her er det selvevaluering og dertilhørende styrkelse af egen forelæsningskompetencer, der identificeres som det mulige attraktive:

"Der kan være nogle fordele for en selv pædagogisk ved, at man ser forelæsningen igen og ser, hvordan det egentlig virker. Også selvom det ikke helt afspejler, hvordan det er i situationen, men det kunne jo være interessant, særligt når man er lidt mere uerfaren underviser. Der er masser af ting, som man ikke selv ved, at man gør, og som man sagtens kunne lære at gøre bedre."

(forelæser 1, pre)

"Der er en evalueringsmæssig fordel. Jeg kan sidde bagefter og se det [...] Jeg ville nok være så nysgerrig, at det ville jeg prøve, for man får et udefra-blik på at se det [...] og det, tænker jeg, er meget lærerigt."

(forelæser 3, pre)

Både studerende og undervisere har dog et ambivalent forhold til fastholdelsen og den deraf følgende fleksibilitet. Underviserne har vi allerede været inde på, men også flere studerende nævner nogle bekymringer og problematikker - dette særligt i forhold til den potentielle situation, at al undervisningen bliver tilgængelig online, og man som studerende ikke behøver møde fysisk op:

"Så længe man ikke bliver helt overladt til sig selv. Jeg synes også, der er en vis socialisering $i$ at være fælles til forelæsninger og snakke lidt sammen i pauserne, om man forstod det osv. Men det kan man selvfølgelig også godt, når man ser det på video."

(studerende 4) 
"[...] man mister rigtig meget socialt. Det, synes jeg, har rigtig meget at sige, at man ser hinanden heroppe. Så får man også lige snakket lidt om projekt i pauserne."

(studerende 6)

Det at møde op og kunne tale samme om både faglige og sociale ting er naturligt en vigtig del af at være studerende. Men uanset undervisnings- og arbejdsform er det et vigtigt aspekt for de studerende, at de kan socialisere med deres medstuderende. I den forbindelse pointerer nogle dog også, at dette måske især er et presserende problem i kraft af, at de er studerende på 1. semester:

"Jeg ville også have haft det svært i starten, for jeg kommer fra Sjælland, og jeg var meget nervøs for, om jeg kunne få nogle venner, og der ville det være et minus, hvis jeg dårligt nok så mine medstuderende. Så jeg synes, det er meget positivt, at vi er så meget sammen, og at vi bliver meget sammentømret i starten. Så kan man måske på de senere semestre begynde og rykke lidt ned på timerne og se mere derhjemme i stedet. Men i starten synes jeg, det er vigtigt, at vi møder meget op og ser nogle mennesker osv."

(studerende 1)

Ligeledes ser forelæserne lignende problematikker i forbindelse med den potentielle virtualisering af forelæsningerne.

" De unge mennesker lever jo et aktivt liv, og der kan sagtens være forelæsninger, hvor de ikke er helt skarpe. Så det giver jo en mulighed for en anden fleksibilitet. Men igen er faren, at de bare vælger at se det en anden dag. I stedet for at det er et forpligtende rum, så bliver det meget et shopping rum. Og som tendens tænker jeg egentlig, at det går lidt imod det, vi gerne vil fremme på 1. semester, nemlig at de studerende ser det her som en arbejdsdag."

(forelæser 2, pre)

"Det er uhensigtsmæssigt, at de studerende ikke er til stede i det primære læringsrum, vi tilbyder. Selvfølgelig tilbyder vi en hel masse, både Moodle og andre måder, men universitetet fysisk er det primære læringsrum, så jeg mener også, at det har betydning for den gruppe - ikke bare projektgruppe - man tilhører. Fx at man på vej ud fra en forelæsning bearbejder nogle ting sammen 
med nogle andre, og det er ikke sikkert, det er forelæsningen, man bearbejder, det kan også være noget socialt. Skrækscenariet er - og så galt tror jeg ikke, det går - at de studerende bare isolerer sig og udelukkende er derhjemme."

(forelæser 3, pre)

Både de studerende og forelæserne er således enige om, at det fysiske fremmøde har nogle kvaliteter, omend disse ikke altid er direkte knyttet til selve forelæsningens indhold, men mere forstås som en bredere socialisering, behandling og diskussion af forelæsningen i en overordnet studiemæssig kontekst. Dette er et potentiale, vi også nærmere vil forfølge i diskussionen.

\section{Opsamling og diskussion}

Det er klart, at de tekniske problemer, vi oplevede, og den deraf følgende afbrydelse af forsøget med livestreaming gør det svært at evaluere, hvorvidt livestreaming kan fungere som supplement til de fysiske forelæsninger. Målet med denne artikel har derfor været at bruge den indsamlede empiri til at diskutere nogle mere principielle problematikker og potentialer ved livestreaming og fastholdelse af forelæsninger.

Der er stærke antydninger i materialet af, at livestreaming og fastholdelse, særlig set fra de studerendes side, kan være nyttigt både i forhold til fleksibilitet og repetition. Dette bekræftes af reviews af en række internationale undersøgelser, som stort set entydigt konkluderer, at studerende er positive over for fastholdelse af undervisning (Heilesen, 2009; Kay, 2012). Ligeledes er der i disse undersøgelser indikationer af, at der kan være læringsmæssige gevinster ved dette. Dog særligt i forbindelse med det, der af Kay (2012) karakteriseres som "test and skill performance", eller som Heilesen formulerer det:

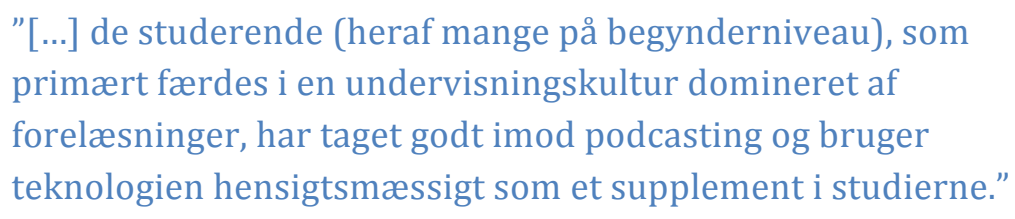

(Heilesen, 2009, p. 15)

Også Rattleff (2008) berører dette potentiale, idet hun argumenterer for, at fastholdelsen kan give rum for bedre læring, fordybelse og øget refleksion. For at realisere dette læringspotentiale, som kan ligge i fastholdte forelæsninger, kræver det dog en didaktisering og stilladsering (som fx en understøttelse af studerendes aktive arbejde med materialet), hvis læringen skal være dybere og mere reflekteret end repetition og basisviden 
(Fibiger, 2010; Heilesen, 2009; Mathiasen, 2010). I vores materiale bemærker vi, at der er forskel på, hvor autoritativt forelæsningen opfattes af henholdsvis studerende og undervisere (hertil skal det dog bemærkes, at det er 1.semesters studerende). Hvor de studerende lader til at tilskrive forelæsningerne stor værdi i henhold til repetition, opgaver og eksamen, er underviserne mere forbeholdne i forhold til forelæsningernes autoritet og betydning for dette formål. Som det bemærkes af en forelæser, kan forelæsningen ikke stå i stedet for de skrevne kilder (lærebogen, forskningsartiklerne etc.), og det er også tydeligt, at forelæsningerne ikke opfattes som det væsentligste læringsrum. Derimod betones vigtigheden af de studerendes egen aktive bearbejdning (notetagning, læsning af tekster, projektarbejde, diskutere, reflektere, udfordre, selektere, spørge etc.). I vores tolkning kan man således se det som en reservation over for at ophøje forelæsningen på bekostning af andre og vigtigere læringsrum; og at der er en reservation over for, at forelæsningerne kan anvendes som kilder eller en slags "audiovisuelt opslagsværk" til en eksamensopgave. I hvert fald er der i vores undersøgelse indikationer på, at der kan være en vis diskrepans mellem de studerendes og forelæsernes opfattelse af forelæsningens autoritet og læringsmæssige potentiale. En væsentlig didaktisk pointe kan derfor være, at det er usikkert, om en fastholdt forelæsning fungerer uden en pædagogisk rammesætning og metakommunikation om, hvorledes den skal 'læses' i en bredere sammenhæng. Her er der naturligvis det forbehold, at vores undersøgelse kun omfatter seks forelæsere, som begrænser sig til samme uddannelse og semester. Det er dog i samme åndedrag værd at notere sig, at størstedelen af de internationale eksperimenter med fastholdelse af undervisningen har fundet sted inden for de teknisk-naturvidenskabelige fag, sprog og sundhedsvidenskaberne (Heilesen, 2009). Der kan ligge nogle faglige forskelle, hvor der kan være varierende behov i relation til repetition og basisviden, og om den enkelte forelæsning forstås som formidling af eksisterende viden eller fx som inspiration til yderligere læsning.

Det kunne være fristende at konkludere, at såfremt det tekniske setup havde fungeret upåklageligt, ville livestreaming fra et lokale til et andet (eller til hjemmet) være mindre problematisk, og at en fastholdelse ville være en ekstra bonus. Der er dog også blandt de studerende nogle reservationer omkring selve medieringen i forhold til koncentration og motivation, og de nævner fx, at det er vigtigt at se "levende billeder", som en studerende lidt ironisk får udtrykt det at være til stede i lokalet. Dette fordi streaming og fastholdelse ikke giver muligheden for direkte interaktion med underviseren, og selvom både undervisere og studerende peger på, at denne i realiteten er sparsom, også i det traditionelle forelæsningsrum, så er muligheden der. I relation til dette fremhæver nogle studerende også vigtigheden af, at de har fornemmelsen af, at underviseren henvender sig til dem, og at 'de er med' og 'velkomne' til forelæsningen, 
dvs. at de kan blive eller bliver adresseret og inkluderet. På den anden side er der også studerende, der indikerer, at dette ikke har den store betydning, når blot streamingen fungerer (og det gjorde den trods alt lejlighedsvis). Der kan altså være en vis variation i, hvordan forskellige studerende oplever og forholder sig til livestreaming i forhold til den oplevede kontakt og behovet for interaktion, hvilket kunne være interessant at undersøge nærmere.

Dette uagtet nævnes der nogle problematikker af både studerende og undervisere. Disse vedrører vigtigheden af at komme fysisk til forelæsningerne, som en del af en bredere studie- og arbejdsmæssig socialiseringsproces, samt at diskutere og reflektere over forelæsningerne. En praksis der kunne blive udfordret af et streaming-tilbud, men på den anden side måske også mere er et forestillet worst-case scenario, snarere end realitet på et on-campus fuldtidsstudie, som underviserne selv antyder. Der er dog indikationer af, at fastholdelse i form af fx podcasts kan mindske studerendes fremmøde (Kay, 2012) (om end det modsatte også fremgår af selvsamme review).

For underviserne gælder det desuden, som også fremhævet af Rattleff og Holm (2009), at der er nogle juridiske og organisatoriske barrierer, som man ikke kan ignorere, fx usikkerhed omkring ledelsesmæssig eller kollegial 'overvågning', overflødiggørelse, kreativ re-appropriering, genbrug og ophavsret. Dette var ikke så udtalt i materialet, og vi oplevede det ikke som en egentlig modstand, men snarere som reservationer og betænkninger, der i højere grad bør overvejes, i fald man vil arbejde studieorganisatorisk med livestreaming og fastholdelse af forelæsninger. Desuden lader undervisernes perspektiv til at være generelt underbelyst, og i fx Kays (2012) review figurerer ingen artikler, hvor dette indgår manifest.

Rattleff og Holm rapporterer ligeledes om nogle psykologiske barrierer, hvor de berører en 'diskrepans' mellem forskning og undervisning. Her peger de på to faktorer: For det første at mange undervisere foretrækker forelæsningsformen, fordi den kan detailplanlægges med fokus på formidling af stoffet, og fordi den således i højere grad afspejler den videnskabelige tekstproduktion. Dermed er den en mere kontrolleret form end den aktive og inddragende pædagogik, som er mere uforudsigelig. I vores materiale kan vi godt genkende Rattleffs og Holms 'diskrepans' mellem forsker og underviser-identitet samt forbeholdene over for det pædagogiske. Men hvor Rattleff og Holm peger på forelæsningen som en mere kontrolleret, formidlende genre, der kan detailplanlægges, finder vi i vores materiale, at underviserne opfatter forelæsningerne som mindre kontrollerede og som mere intime, følsomme, situerede og improviserede begivenheder. Dette gælder dels for selve den mere personlige optræden, men også i relation til det faglige indhold, hvor det lader til, at dette kan 
være mere eksplorativt, perspektiverende eller eksperimenterende. Så hvor Rattleff og Holm metaforisk sammenligner forelæsningen med forskningsartiklen, vil vi pege på, at nogle forelæsninger i højere grad kan forstås som et workshop- eller konference-paper. Dette kan også være med til at forklare reservationerne over for studerendes brug af forelæsningen som audio-visuelle opslagsværker i forbindelse med eksamen.

Det er endvidere tydeligt i vores materiale, at selvom forelæsningen i princippet er offentlig, så opfattes forelæsningsrummet som et mere intimt semi-offentligt rum, hvor der er plads til vittigheder, improvisation og kontroversielle udmeldinger. Dette betyder noget for forberedelse, og for hvad man kan tillade sig at tage med i forelæsningen, når den foreviges. Det betyder også, at det er kommunikation, der er situeret i en bestemt kontekst, med en intenderet modtagergruppe, og måske med særligt aktuelle emner (fx noget, der har været i pressen om morgenen), som derfor kan give nogle usikkerheder om egnetheden i relation til enten et bredere publikum eller til de studerende året efter.

I den forbindelse vil vi fremhæve, at livestreaming og fastholdelse på sin vis medfører en hybrid-genre, når den pludselig kan fastholdes og udlejres fra det intime, semi-offentlige rum til en mere diffus offentlighed. Således bliver nogle af de styrker og værdier, som underviserne tillægger forelæsningen (det initime, situerede, improviserede og ufærdige) udfordret af udlejringen. Der kan fra undervisers side potentielt ske det, at der kommer mere udtryks- og indholdskontrol samt selv-censur. I den forstand kan man måske tale om, at der opstår en lidt forvirret hybridgenre mellem forelæsningen og det kontrollerede foredrag, som en af respondenterne også er inde på.

Det er dog vigtigt, at vi ikke ignorerer, at der faktisk kan ligge nogle potentialer i livestreaming og fastholdelse af forelæsninger. Som vi kan se af de studerendes respons, kan der være et positivt element $i$, at forelæsningen kan gøres til genstand for en løbende diskussion og meningsforhandling blandt de studerende (som det i en vis udstrækning fandt sted i de tilstreamede lokaler); og som Rattleff og Holm (2009) peger på, kan det være en god ressource på uddannelser, hvor fleksibilitet $\mathrm{i}$ forhold til tilstedeværelse er en nødvendighed.

Sidst vil vi fremhæve, at vi modsat Rattleff og Holm ikke har oplevet en egentlig modstand mod forsøget. Vi har oplevet og kan læse ud af materialet, at der er nogle reservationer omkring ledelsesmæssig eller kollegial 'overvågning', overflødiggørelse, kreativ re-appropriering, genbrug og ophavsret. Ligeledes er der nogle forbehold, som vi primært ser som en reaktion på de indbyggede spændinger eller konflikter, der ligger i den hybridgenre, som opstår ved fastholdelse af en livestreaming. I modsætning til det planlagte, kontrollede foredrag er forelæsningsrummet 
til tider mere eksplorativt, sårbart, improviseret og intimt, og udfordres derfor ved udlejringen i en mere diffus offentlighed. Disse spændinger og kontraster, mener vi, er vigtige i forhold til at forstå og håndtere nogle af de udfordringer, der kan opstå i forbindelse med livestreaming og fastholdelse af forelæsninger. Særligt fordi "modstand" mod nye teknologier ofte læses eller italesættes som bagstræberiskhed hos undervisere. Bagved sådan en modstand kan gemme sig mere nuancerede og legitime reservationer, som er væsentlige og vigtige at forstå. 


\section{Referencer}

Cherubini, M., de Oliveira, R., Oliver, N., \& Ferran, C. (2010). Gaze and Gestures in Telepresence: multimodality, embodiment, and roles of collaboration (arXiv e-print No. 1001.3150). Retrieved from http://arxiv.org/abs/1001.3150

Fibiger, B. (2010). Mobile mediers læringspotentialer - didaktiske overvejelser i forbindelse med brugen af podcast og vodcast. Tidsskriftet Læring og Medier (LOM), 3(5). Retrieved from http://ojs.statsbiblioteket.dk/index.php/lom/article/view/3950

Garrison, D. R., Anderson, T., \& Archer, W. (1999). Critical Inquiry in a TextBased Environment: Computer Conferencing in Higher Education. The Internet and Higher Education, 2(2-3), 87-105. doi:10.1016/S10967516(00)00016-6

Heilesen, S. (2009). Om erfaringer med podcasts i universiteternes undervisning. Tidsskriftet Læring og Medier (LOM), 2(2). Retrieved from http://ojs.statsbiblioteket.dk/index.php/lom/article/view/3909

Heilesen, S. (2010). What is the academic efficacy of podcasting? Computers \& Education, 55(3), 1063-1068. doi:10.1016/j.compedu.2010.05.002

Højsgaard, L. (2013, November). E-læring skaber nye ophavsretudfordringer. Forskerforum, (269), 12.

Kay, R. H. (2012). Exploring the use of video podcasts in education: A comprehensive review of the literature. Computers in Human Behavior, 28(3), 820-831. doi:10.1016/j.chb.2012.01.011

Kvale, S. (1997). InterView - en introduktion til det kvalitative forskningsinterview. Hans Reitzels Forlag.

Mathiasen, H. (2010). Brug af podcasts i undervisningen - muligheder og begrænsninger. Tidsskriftet Læring og Medier (LOM), 3(5). Retrieved from http://ojs.statsbiblioteket.dk/index.php/lom/article/view/3955

McBrien, J. L., Cheng, R., \& Jones, P. (2009). Virtual Spaces: Employing a Synchronous Online Classroom to Facilitate Student Engagement in Online Learning. The International Review of Research in Open and Distance Learning, 10(3). Retrieved from http://www.irrodl.org/index.php/irrodl/article/view/605

Moore, M. G. (1993). Theory of Transactional Distance. In D. Keegan (Ed.), Theoretical principles of distance education (pp. 22-38). New York: Routledge.

Rattleff, P. (2008). Studerendes brug af videostreamet universitetsundervisning. In L. B. Andreasen, B. Meyer, \& P. Rattleff (Eds.), Digitale medier og didaktisk design (1st ed., pp. 212-235). Danmarks Pædagogiske Universitetsforlag. 
Rattleff, P., \& Holm, L. G. (2009). Barrierer for ibrugtagning af videooptaget universitetsundervisning. Tidsskriftet Læring og Medier (LOM), 2(2). Retrieved from http://ojs.statsbiblioteket.dk/index.php/lom/article/view/3911

Teng, D. C.-E., Chen, N.-S., Kinshuk, \& Leo, T. (2012). Exploring students' learning experience in an international online research seminar in the Synchronous Cyber Classroom. Computers \& Education, 58(3), 918-930. doi:10.1016/j.compedu.2011.10.018 